\title{
Effects of common groundwater ions on chromate removal by magnetite: importance of chromate adsorption
}

\author{
Amanda H. Meena ${ }^{1}$ and Yuji Arai ${ }^{2^{*}}$
}

\begin{abstract}
Background: Reductive precipitation of hexavalent chromium ( $\mathrm{Cr}(\mathrm{VI}))$ with magnetite is a well-known $\mathrm{Cr}(\mathrm{VI})$ remediation method to improve water quality. The rapid (<a few $\mathrm{hr}$ ) reduction of soluble $\mathrm{Cr}(\mathrm{VI})$ to insoluble $\mathrm{Cr}(\mathrm{III})$ species by $\mathrm{Fe}(\mathrm{II})$ in magnetite has been the primary focus of the $\mathrm{Cr}(\mathrm{VI})$ removal process in the past. However, the contribution of simultaneous $\mathrm{Cr}(\mathrm{VI})$ adsorption processes in aged magnetite has been largely ignored, leaving uncertainties in evaluating the application of in situ $\mathrm{Cr}$ remediation technologies for aqueous systems. In this study, effects of common groundwater ions (i.e., nitrate and sulfate) on $\mathrm{Cr}(\mathrm{VI})$ sorption to magnetite were investigated using batch geochemical experiments in conjunction with X-ray absorption spectroscopy.

Results: In both nitrate and sulfate electrolytes, batch sorption experiments showed that $\mathrm{Cr}(\mathrm{VI})$ sorption decreases with increasing $\mathrm{pH}$ from 4 to 8 . In this $\mathrm{pH}$ range, $\mathrm{Cr}(\mathrm{VI})$ sorption decreased with increasing ionic strength of sulfate from 0.01 to $0.1 \mathrm{M}$ whereas nitrate concentrations did not alter the $\mathrm{Cr}(\mathrm{VI})$ sorption behavior. This indicates the background electrolyte specific $\mathrm{Cr}(\mathrm{VI})$ sorption process in magnetite. Under the same ionic strength, $\mathrm{Cr}(\mathrm{VI})$ removal in sulfate containing solutions was greater than that in nitrate solutions. This is because the oxidation of Fe(II) by nitrate is more thermodynamically favorable than by sulfate, leaving less reduction capacity of magnetite to reduce $\mathrm{Cr}(\mathrm{VI})$ in the nitrate media. X-ray absorption spectroscopy analysis supports the macroscopic evidence that more than $75 \%$ of total $\mathrm{Cr}$ on the magnetite surfaces was adsorbed $\mathrm{Cr}(\mathrm{VI})$ species after $48 \mathrm{~h}$.
\end{abstract}

Conclusion: This experimental geochemical study showed that the adsorption process of $\mathrm{Cr}(\mathrm{VI})$ anions was as important as the reductive precipitation of $\mathrm{Cr}(\mathrm{III})$ in describing the removal of $\mathrm{Cr}(\mathrm{VI})$ by magnetite, and these interfacial adsorption processes could be impacted by common groundwater ions like sulfate and nitrate. The results of this study highlight new information about the large quantity of adsorbed $\mathrm{Cr}(\mathrm{VI})$ surface complexes at the magnetitewater interface. It has implications for predicting the long-term stability of $\mathrm{Cr}$ at the magnetite-water interface.

Keywords: Chromate, Cr, Groundwater lons, Magnetite, Adsorption, Surface Speciation, Reduction, Sulfate, Nitrate, $X$-ray absorption spectroscopy

\section{Background}

Hexavalent chromium [Cr(VI) or chromate], has been recognized as one of the major toxic substances by the United States Environmental Protection Agency (USEPA) [1] because of its carcinogenic effects [2]. In a recent report by Environmental Working Group, [Cr(VI)]

\footnotetext{
${ }^{*}$ Correspondence: yarai@illinois.edu

${ }^{2}$ Department of Natural Resources and Environmental Sciences,

University of Illinois at Urbana-Champaign, Urbana, IL 61801, USA

Full list of author information is available at the end of the article
}

in tap water tested from 25 out of 35 American cities was greater than a proposed limit of $0.06 \mu \mathrm{g} \mathrm{L}^{-1}$ by the state of California EPA [3]. While the occurrence of $\mathrm{Cr}$ in these water resources is contributed by anthropogenic (e.g., steel mills, leather-tanning facilities) and indigenous sources (weathering of rocks and soils), there is an imminent interest to reduce the concentration of $\mathrm{Cr}$ from drinking water resources.

The reduction of $\mathrm{Cr}(\mathrm{VI})$ by synthetic magnetite has been frequently studied for the remediation of $\mathrm{Cr}(\mathrm{VI})$ 
contaminated waters in the past [4-7]. In a $\mathrm{Cr}(\mathrm{VI})$ tetrahedral ion, $t_{2 g}$ and e.g. orbitals are empty. It accepts three electrons from the $t_{2 g}$ (pi) orbital of three ferrous ions, filling half of the $t_{2 g}$ orbital, $\mathrm{Cr}$ (III). It is at the ground-state electron configuration in an octahedral environment. It is well documented that $\mathrm{Fe}(\mathrm{II})$ in magnetite facilitates the reduction of $\mathrm{Cr}(\mathrm{VI})$ to $\mathrm{Cr}(\mathrm{III})$, subsequently forming $\mathrm{Cr}$ (III) hydroxide and or a mixed $\mathrm{Cr}$ (III)-Fe(III) hydroxide surface precipitate at the surface of an iron oxide [8-11]. These reductive precipitation reactions often refer to $\mathrm{Cr}(\mathrm{VI})$ sorption to magnetite. It is important to note that the term, sorption, was used to describe both precipitation and adsorption reactions on the mineral surfaces throughout the text. The $\mathrm{Cr}(\mathrm{VI})$ sorption reaction in magnetite is $\mathrm{pH}$ dependent. Sorption increases with decreasing $\mathrm{pH}[4,6,12]$. Based on the following half-reactions $1-3[13,14]$, overall reactions of $\mathrm{Cr}(\mathrm{VI})$ reduction by $\mathrm{Fe}(\mathrm{II})$ can be written in reactions 4 and 5 .

$$
\begin{aligned}
& \mathrm{CrO}_{4}^{2-}+8 \mathrm{H}^{+}+3 \mathrm{e}^{-} \longrightarrow \mathrm{Cr}^{3+} \\
& +4 \mathrm{H}_{2} \mathrm{O} \quad E^{\mathrm{o}}(\mathrm{V})=-0.11 \text { volts } \\
& 3 \mathrm{Fe}^{2+}+4 \mathrm{H}_{2} \mathrm{O} \longrightarrow \mathrm{Fe}_{3} \mathrm{O}_{4} \\
& +8 \mathrm{H}^{+}+2 \mathrm{e}^{-} \quad \mathrm{E}^{\mathrm{o}}(\mathrm{V})=1.08 \text { volts } \\
& \mathrm{Fe}^{2+} \longrightarrow \mathrm{Fe}^{3+}+\mathrm{e}^{-} \quad \mathrm{E}^{\mathrm{o}}=-0.777 \text { volts } \\
& 2 \mathrm{CrO}_{4}^{2}+9 \mathrm{Fe}^{2+}+4 \mathrm{H}_{2} \mathrm{O} \longrightarrow 2 \mathrm{Cr}^{3+}+3 \mathrm{Fe}_{3} \mathrm{O}_{4}+8 \mathrm{H}^{+} \\
& \mathrm{CrO}_{4}^{2-}+3 \mathrm{Fe}^{2+}+8 \mathrm{H}^{+} \longrightarrow \mathrm{Cr}^{3+}+3 \mathrm{Fe}^{3+}+4 \mathrm{H}_{2} \mathrm{O}
\end{aligned}
$$

Kendelewicz and other researchers postulated a twostep mechanism to explain the $\mathrm{Cr}(\mathrm{VI})$ sorption process: electrostatic attraction of $\mathrm{Cr}(\mathrm{VI})$ anions, followed by the electron transfer reaction between $\mathrm{Cr}(\mathrm{VI})$ and the structural $\mathrm{Fe}(\mathrm{II})$ to form $\mathrm{Cr}(\mathrm{III})(\mathrm{OH})_{3}[8,12,15,16]$. The $\mathrm{Cr}(\mathrm{VI})$ reduction mechanism was accompanied by simultaneous homogenous oxidation of $\mathrm{Fe}(\mathrm{II})$ released by passivation of magnetite [7]. Especially at basic conditions, $\mathrm{Fe}(\mathrm{II})$ in magnetite is highly susceptible to autooxidation, resulting in a decrease in $\mathrm{Cr}(\mathrm{VI})$ reduction [12]. Although the above sorption mechanisms were suggested, it is poorly understood how these steps are interfered by common ions in natural and waste waters. Our water resources usually contain ions like nitrate and sulfate that could potentially interfere with the formation of $\mathrm{Cr}(\mathrm{VI})$ precursor complex on the magnetite surface and or electron transfer reactions. This could potentially result in ineffective $\mathrm{Cr}(\mathrm{VI})$ immobilization with magnetite. Nitrate concentration in surface water ranges from 0.1 to $20 \mathrm{mg} \mathrm{L}^{-1}$, and it can be as high as $30 \mathrm{mg} \mathrm{L}^{-1}$ in wastewater [17]. Sulfate in domestic sewage effluents can be as high as $500 \mathrm{mg} \mathrm{L}^{-1}$, and up to several thousand $\mathrm{mg} \mathrm{L}^{-1}$ in some industrial effluents [18]. It is possible that these anions can potentially interfere with $\mathrm{Cr}(\mathrm{VI})$ immobilization by magnetite via (1) competitive adsorption of nitrate and sulfate and (2) competitive electron transfer reactions.

In general, the strength of oxyanion complexation on metal oxyhydroxide surfaces can be predicted using the shared charge value (SCV), which is the positive oxyanion charge divided by the number of bonded $\mathrm{O}$ atoms. The lower the SCV, the stronger the affinity of oxyanion sorption. The SCV for $\mathrm{NO}_{3}{ }^{-}$is 1.67 while $\mathrm{SO}_{4}{ }^{2-}$ and $\mathrm{CrO}_{4}{ }^{2-}$ both have a SCV of 1.5 , indicating that the latter oxyanions have a slightly stronger metal-oxyanion ionic bond. Based on the SCV, one can expect that nitrate will not strongly perturb the initial $\mathrm{CrO}_{4}{ }^{2-}$ adsorption step. However, sulfate could compete for sorption sites, resulting in less chromate sorption and or suppression of electron transfer reactions.

Competitive $\mathrm{Fe}(\mathrm{II})$ redox reactions by nitrate could also influence $\mathrm{Cr}(\mathrm{VI})$ reduction. Based on the standard state redox potential of half-reactions [13] and $\Delta \mathrm{G}^{\mathrm{o}}=-\mathrm{n} F\left(\mathrm{E}_{\mathrm{ox}}^{\mathrm{o}}+\mathrm{E}_{\mathrm{red}}^{\mathrm{o}}\right)$, where $\mathrm{n}$ is the number of moles of $\mathrm{e}^{-}$from balanced redox reaction and $F$ is the Faraday constant $\left(96,487 \mathrm{~J} \mathrm{~V}^{-1} \mathrm{~mol}^{-1}\right)$, it is clear that the thermodynamic favorability of the reduction of $\mathrm{Cr}(\mathrm{VI})$ by $\mathrm{Fe}(\mathrm{II})$ is most preferred over the reduction of nitrate/ sulfate under the equilibrium condition. However, if $\mathrm{Cr}(\mathrm{VI})$ co-exists with nitrate, $\mathrm{Fe}(\mathrm{II})$ in magnetite, as surface bound/crystal defects, could potentially be depleted by the reduction of nitrate, resulting in less $\mathrm{Cr}(\mathrm{VI})$ reduction. Kinetically controlled effects cannot be excluded.

$$
\begin{aligned}
& \mathrm{Cr}_{2} \mathrm{O}_{7}^{2-}+14 \mathrm{H}^{+}+6 \mathrm{e}^{-} \longrightarrow 2 \mathrm{Cr}^{3+}+7 \mathrm{H}_{2} \mathrm{O} \\
& E^{\mathrm{o}}=+1.36 \text { volts } \\
& \mathrm{NO}_{3}^{-}+10 \mathrm{H}^{+}+8 \mathrm{e}^{-} \longrightarrow \mathrm{NH}_{4}^{+}+3 \mathrm{H}_{2} \mathrm{O} \\
& E^{\mathrm{o}}=+0.882 \text { volts } \\
& \mathrm{NO}_{3}^{-}+2 \mathrm{H}^{+}+2 \mathrm{e}^{-} \longrightarrow \mathrm{NO}_{2}^{-}+\mathrm{H}_{2} \mathrm{O} \\
& E^{\mathrm{o}}=+0.837 \text { volts } \\
& \mathrm{SO}_{4}^{2-}+9 \mathrm{H}^{+}+8 \mathrm{e}^{-} \longrightarrow \mathrm{HS}^{-}+4 \mathrm{H}_{2} \mathrm{O} \\
& E^{\mathrm{o}}=+0.248 \text { volts }
\end{aligned}
$$

The objective of this study was to investigate the effects of nitrate and sulfate on $\mathrm{Cr}(\mathrm{VI})$ removal by magnetite, as a function of $\mathrm{pH}$ and ionic strength (0.01 vs. $0.1)$ through batch sorption experiments. As reviewed above, numerous investigations in the same system [i.e., 

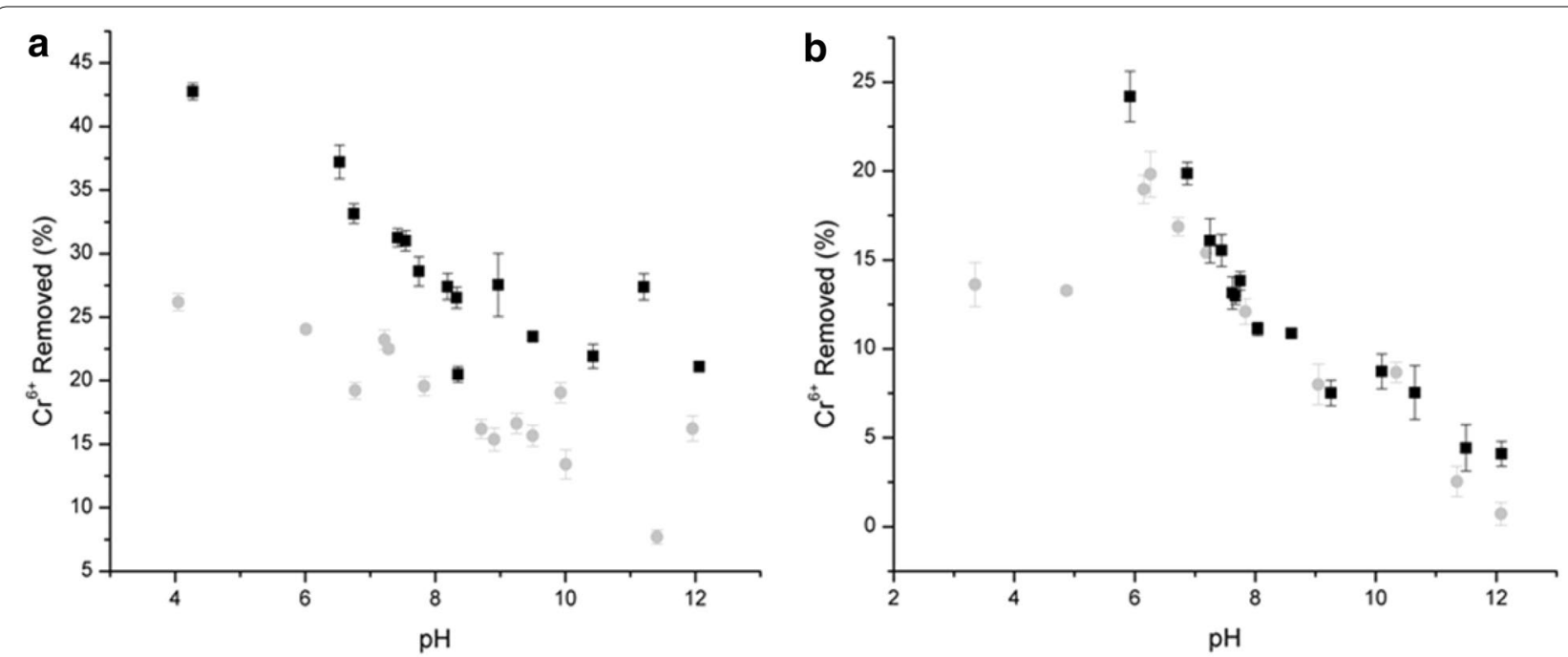

Fig. 1 Chromate sorption envelopes in magnetite after $24 \mathrm{~h}$ in the following background electrolyte solutions a $\mathrm{Na}_{2} \mathrm{SO}_{4}$ b $\mathrm{NaNO}_{3}$. Black squares and grey circles represent low $\left(0.0016 \mathrm{M} \mathrm{Na}_{2} \mathrm{SO}_{4}, 0.01 \mathrm{M} \mathrm{NaNO}_{3}\right)$ and high $\left(0.016 \mathrm{M} \mathrm{Na}_{2} \mathrm{SO}_{4}, 0.1 \mathrm{M} \mathrm{NaNO}_{3}\right)$ ionic strengths, respectively

$\mathrm{Cr}(\mathrm{VI})$ in magnetite] were dedicated to the characterization of reaction products in corroded magnetite. This study, instead, focuses on the macroscopic behavior of the $\mathrm{Cr}(\mathrm{VI})$ removal process by magnetite in two different electrolyte systems. To understand the effect of these electrolytes on the Cr surface species, in situ Cr K-edge $\mathrm{X}$-ray absorption spectroscopy (XAS) measurements were also conducted. These analyses allow for a greater understanding of the $\mathrm{Cr}(\mathrm{VI})$ removal capacity of magnetite in natural water systems.

\section{Results and discussion PZSE of magnetite}

The PZSE of magnetite used in this study was determined using batch titrations with $0.01,0.05$ and $0.1 \mathrm{M} \mathrm{NaNO}_{3}$, and was approximately 5.63 , slightly lower than reported PZSE and PZC values of synthetic magnetite, 6.3-6.8 [12, 19, 20]. Salazar-Camacho and co-workers also reported the isoelectric point (IEP) of two nano-magnetite samples to be 6.2 for $<5 \mu \mathrm{m}$ and 6.7 for $<50 \mathrm{~nm}$ particles [21]. This discrepancy may be due to surface oxidation and or impurities [22-24]. In the literature, comparatively lower PZSE values have been reported with natural magnetite samples $[21,25,26]$.

\section{Pseudo-equilibrium sorption experiments}

The results of $\mathrm{CrO}_{4}{ }^{2-}$ sorption envelope experiments in magnetite are shown in Fig. 1. In the following sections, macroscopic behavior of chromate sorption to magnetite is discussed in terms of $\mathrm{pH}$, ionic strength, and type of electrolytes $\left(\mathrm{NaNO}_{3}\right.$ and $\left.\mathrm{Na}_{2} \mathrm{SO}_{4}\right)$.

\section{Effects of $\mathrm{pH}$}

In both electrolytes, chromate sorption is $\mathrm{pH}$ dependent. The sorption generally increases with decreasing $\mathrm{pH}$ from 10 to 4 although a few data points at $\mathrm{pH}<5$ (Fig. 1b) are influenced by the dissolution of solids. Similar $\mathrm{pH}$ dependent chromate sorption behavior has been documented in several studies [4-6, 12, 27, 28]. Assuming that $\mathrm{Cr}(\mathrm{VI})$ is present, the sorption trend can be explained by the aqueous speciation of chromate and the surface charge density of magnetite at given $\mathrm{pH}$ values.

Aqueous speciation of chromate under all conditions was calculated using Visual MINTEQ version 3.0 [29]. In both electrolytes, negatively charged chromate species are generally observed (Fig. 2). The $\mathrm{HCrO}_{4}{ }^{-}$species is dominant at approximately $\mathrm{pH}<6$ and $\mathrm{CrO}_{4}{ }^{2-}$ at $\mathrm{pH}$ $>6$ with a minor contribution from $\mathrm{NaCrO}_{4}{ }^{-}$species. The dissociation constant of hydrogen chromate $\left(3.1 \times 10^{-7}\right.$, pKa 6.51) agrees with the predominance of $\mathrm{CrO}_{4}{ }^{2-}$ as the major aqueous species at experimental $\mathrm{pH}$ values $4-10$ [30].

At $\mathrm{pH}<5$ (below PZSE of magnetite), surfaces of magnetite are positively charged. Chromate anions are expected to be strongly attracted to the surfaces via electrostatic interactions. This supports a 1st step to form the precursor complex prior to the electron transfer reaction suggested by Kendelewicz and co-workers [8, 15].

At $\mathrm{pH}>5$, more negatively charged surfaces will be developed, further reducing the attraction of anions, like chromate. However, some sorption occurred at $\mathrm{pH}$ 8-11, possibly suggesting inner-sphere sorption mechanisms via ligand exchange reactions. 


\section{Effects of ionic strength}

Although there are some variable data points in each electrolyte experiment (Fig. 1a, b), one can clearly see two distinct ionic strength effects on $\mathrm{CrO}_{4}{ }^{2-}$ sorption. In the sulfate media, $\mathrm{Cr}(\mathrm{VI})$ uptake was affected by changes in ionic strength. The sorption drastically decreased when ionic strength was increased from 0.0016 to $0.016 \mathrm{M}$ sulfate at $\mathrm{pH} 3-12$. Average $\mathrm{Cr}(\mathrm{VI})$ removal is $10.4 \%$ lower at higher sulfate concentration. White and Peterson also previously reported the effects of $\mathrm{SO}_{4}{ }^{2-}$ concentrations (0.01-0.1 M) on chromate sorption [7]. On the other hand, little effect of ionic strength effect was observed in the nitrate media. This observation is consistent with other studies that found negligible effects of $\mathrm{NO}_{3}{ }^{-}$concentration on $\mathrm{Cr}(\mathrm{VI})$ removal by magnetite [31].

Hayes and co-workers previously proposed an indirect macroscopic method for distinguishing innersphere from outer-sphere complexes by examining ionic strength effects of inert electrolytes on oxyanion sorption envelopes coupled with the generalized triple layer model [32]. Accordingly, inner-sphere complexes are not greatly affected by ionic strength, whereas the presence of outersphere complexes is indicated by a shift in the $\mathrm{pH}$ with changing ionic strength due to competitive sorption with counter anions. Based on the theory, one can suggest that chromate predominantly forms inner-sphere complexes in the $\mathrm{NaNO}_{3}$ media at $\mathrm{pH} 4-11$, whereas chromate could adsorb to magnetite as a mixture of inner- and outer-sphere complexes in the $\mathrm{Na}_{2} \mathrm{SO}_{4}$ media. In the high ionic strength of $\mathrm{Na}_{2} \mathrm{SO}_{4}$, it is possible that the surface speciation of chromate is predominantly inner-sphere complexes at $\mathrm{pH}$ 6-12. These interpretations of sorption mechanisms, however, are contradicted in two different background electrolyte media, which is likely attributed to differences in inertness between nitrate and sulfate ions and or redox reaction at the surfaces. The macroscopic observation is useful in evaluating chromate removal from aqueous solution under different reaction conditions. However, the removal of $\mathrm{Cr}(\mathrm{VI})$ from solution should not be interpreted as the chemi-sorption of $\mathrm{Cr}(\mathrm{VI})$ anions in magnetite without any spectroscopic evidence. In the XAS analysis section below, chemical speciation of $\mathrm{Cr}$ on magnetite surfaces is discussed.

\section{Effects of sulfate and nitrate}

When the total Cr retention was compared in these electrolyte systems (Fig. 1), the sulfate system yielded more $\mathrm{Cr}$ retention by magnetite. Based on the SCV argument discussed above, sulfate should have interfered with the adsorption of $\mathrm{CrO}_{4}{ }^{2-}$. However, this is not the case. The nitrate system yielded less $\mathrm{Cr}$ retention. It is likely that a different factor was involved in the reactions (Fig. 1). As reported by several previous studies [4-7], Cr(VI) uptake by magnetite is attributed to the reduction of $\mathrm{Cr}(\mathrm{VI})$ by $\mathrm{Fe}(\mathrm{II})$ in magnetite. If the surface bound $\mathrm{Fe}(\mathrm{II})$ and the $\mathrm{Fe}(\mathrm{II})$ in crystal defects are consumed by other anions like nitrate, the presence of nitrate should lower the reduction of $\mathrm{Cr}(\mathrm{VI})$, resulting in less $\mathrm{Cr}$ uptake by magnetite. When $\Delta \mathrm{G}^{\mathrm{o}}$ of oxyanion reduction was estimated using the half reaction Eqs. 3 and $6-9, \mathrm{Cr}(\mathrm{VI})$ reduction is most favorable $\left(\Delta G^{\circ}=-56.25 \mathrm{~kJ}\right)$, followed by nitrate reduction to nitrite $\left(\Delta \mathrm{G}^{\mathrm{o}}=-11.57 \mathrm{~kJ}\right)$, nitrate reduction to ammonium $\left(\Delta \mathrm{G}^{\mathrm{o}}=-10.13 \mathrm{~kJ}\right)$, and sulfate reduction to bisulfide $\left(\Delta \mathrm{G}^{\circ}=385.17 \mathrm{~kJ}\right)$. This clearly suggests that sulfate reduction does not favorably occur at the standard state. However, nitrate could competitively oxidize surface available $\mathrm{Fe}(\mathrm{II})$ in magnetite. Although kinetics of competitive chromate and nitrate reduction was not measured in this research, it is clear that nitrate was more competitively oxidizing Fe(II) than sulfate, possibly resulting in less $\mathrm{Cr}$ retention in the nitrate system.

\section{XAS analysis}

To better assess the macroscopic observation discussed above, the chemical speciation of $\mathrm{Cr}$ on the magnetite surface was investigated using XAS. Effects of ionic strength, $\mathrm{pH}$ and kinetics on the $\mathrm{Cr}$ surface speciation are discussed below.

\section{Effect of ionic strength on $\mathrm{Cr}$ surface speciation}

A calibration curve of the $\mathrm{Cr}$ chemical state was constructed using XANES spectra of $\mathrm{Cr}(\mathrm{VI}) / \mathrm{Cr}(\mathrm{III})$ salt mixtures (Fig. 3). The intensity of the pre-edge peak intensifies with increasing $\mathrm{Cr}(\mathrm{VI})$ content. There is a near linear relationship between the pre-edge peak height and $\% \mathrm{Cr}(\mathrm{VI}) / \mathrm{Cr}_{\text {total }}$. Fig. $4 \mathrm{a}$ and c show the pre-edge features of normalized Cr K-edge XANES spectra in both nitrate and sulfate systems. To facilitate the comparison, the $\% \mathrm{Cr}(\mathrm{VI})$ fraction in sorption samples was estimated using the XANES calibration curve. It is important to note that "\% $\mathrm{Cr}(\mathrm{VI})$ on the surface" in Fig. 4 is different from the results of macroscopic data shown in Fig. 1, which presents the "\% Cr removed" from the aqueous system. The following discussion is organized based on the type of background electrolyte.

In the sulfate media (Fig. 4a, b), the amount of $\mathrm{Cr}(\mathrm{VI})$ on the magnetite surface was dependent on ionic strength under respective $\mathrm{pH}$ values. At basic $\mathrm{pH}$ values, low $(0.0016 \mathrm{M})$ sulfate facilitated a very small amount of $\mathrm{Cr}(\mathrm{VI})(\sim 0.1 \%)$ on the surface [i.e., $\sim 100 \%$ of surface $\mathrm{Cr}$ is $\mathrm{Cr}(\mathrm{III})]$. $\mathrm{Cr}(\mathrm{III})(\mathrm{OH})_{3}(\mathrm{~s})$ surface species are likely dominant at alkaline conditions. At acidic $\mathrm{pH}$ values, low sulfate yielded a large amount of $\mathrm{Cr}(\mathrm{VI})(60.4 \%)$. Chromate was strongly adsorbed on Fe octahedral sites of the magnetite structure. As previously discussed, the shared charge value of sulfate (1.5) is smaller than that of nitrate 

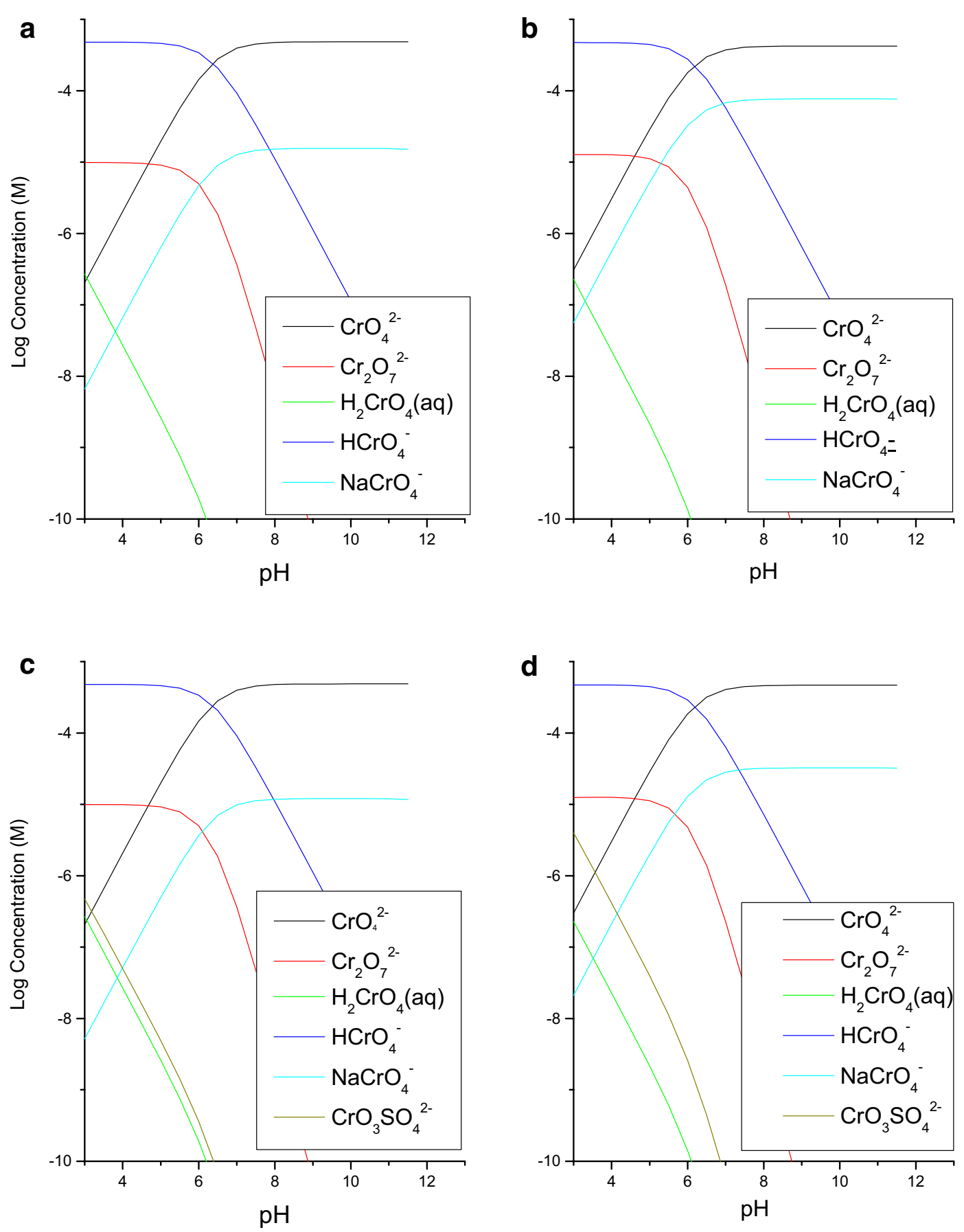

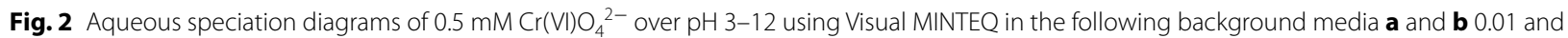
$0.1 \mathrm{M} \mathrm{NaNO}_{3}$, respectively. c and $\mathbf{d} 0.0016$ and $0.016 \mathrm{M} \mathrm{Na}_{2} \mathrm{SO}_{4}$, respectively

(1.67), suggesting the greater affinity of sulfate on metal oxide surfaces. Its strong sorption mechanism has been well documented in different iron oxyhydroxide minerals. In goethite, $\mathrm{CrO}_{4}{ }^{2-}$ sorption occurs via inner-sphere complexation at near neutral $\mathrm{pH}$ values [33-36]. The potential for any background oxyanion to force the formation of a $\mathrm{Cr}(\mathrm{VI})$ inner-sphere surface complex could also facilitate the reduction of $\mathrm{Cr}(\mathrm{VI})$ at the magnetite surface. Considering the positively charged magnetite surfaces at acidic $\mathrm{pH}$, chromate anions should be strongly 

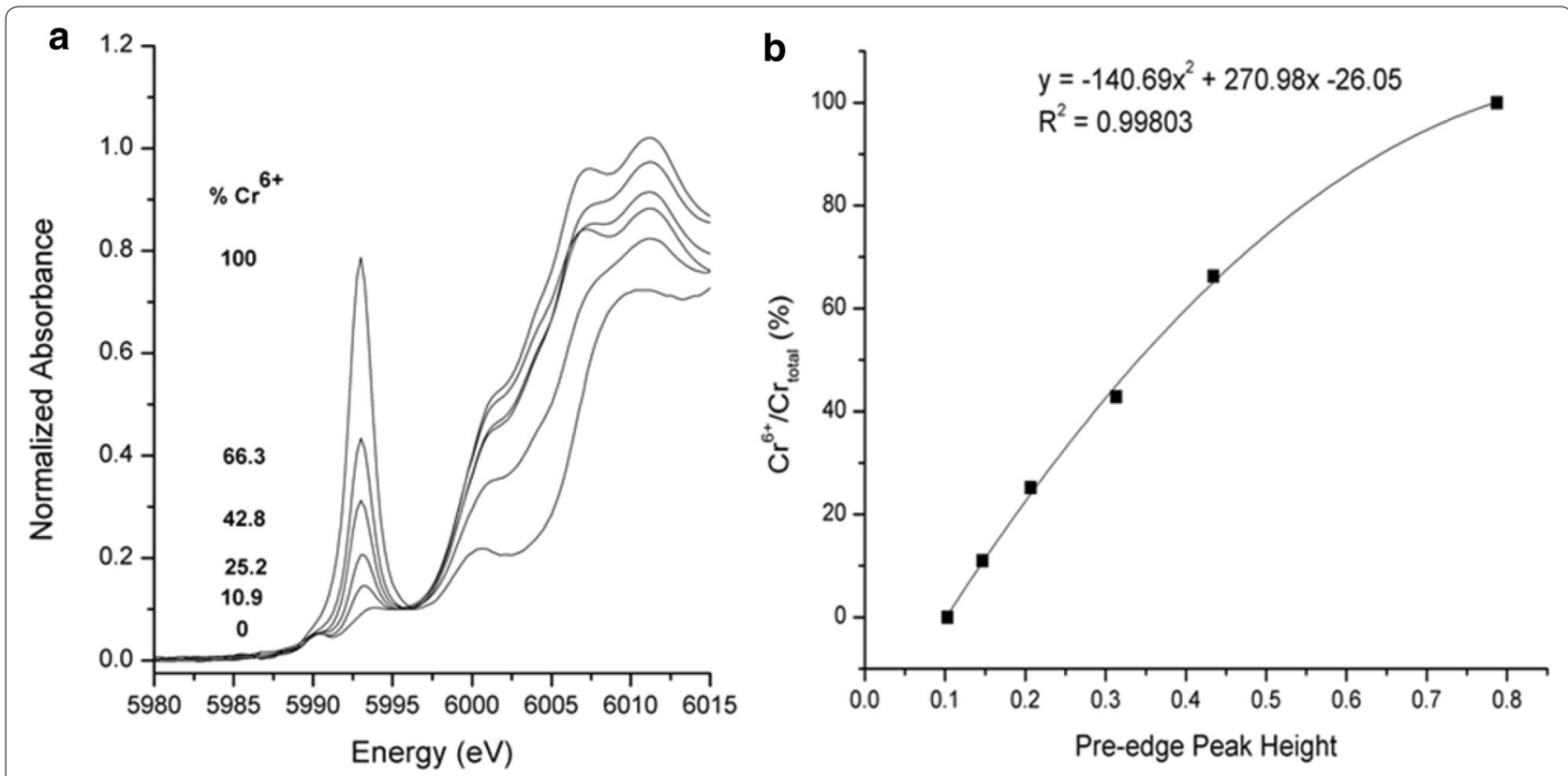

Fig. 3 a Pre-edge features of bulk XANES spectra of reference salt mixtures $\left(\mathrm{K}_{2} \mathrm{Cr}(\mathrm{VI}) \mathrm{O}_{4}\right.$ and $\left.\mathrm{Cr}_{2}(\mathrm{III}) \mathrm{O}_{3}\right)$ b The intensity of $\mathrm{Cr}(\mathrm{VI})$ pre-edge height of reference spectra in Fig. 3a as a function of $\mathrm{Cr}(\mathrm{VI}) / \mathrm{Total} \mathrm{Cr}(\%)$

attracted. However, high $(0.016 \mathrm{M})$ sulfate at acidic $\mathrm{pH}$ resulted in low $\mathrm{Cr}$ (VI) $(1.7 \pm 0.2 \%)$ on the surface. Competitive sulfate adsorption in the high sulfate condition might be responsible for this $\mathrm{pH}$ dependent $\mathrm{Cr}$ removal from solution (Fig. 1).

In the nitrate media (Fig. 4c, d), there was a similar ionic strength dependency in the $\mathrm{Cr}(\mathrm{VI})$ surface speciation. At acidic $\mathrm{pH}$, the fraction of $\mathrm{Cr}(\mathrm{VI})$ increased from $\sim 16$ to $91.4 \%$ with decreasing ionic strength. High [nitrate] possibly competes with the chromate anion, resulting in less $\mathrm{Cr}(\mathrm{VI})$ sorption under the high nitrate condition. At basic $\mathrm{pH}$ values, there was an opposite trend. Surface $\mathrm{Cr}(\mathrm{VI})$ increased from $\sim 6.1$ to $\sim 30 \%$ with increasing ionic strength. At alkaline $\mathrm{pH}$, total $\mathrm{Cr}$ removal was not strongly affected by changes in ionic strength. Therefore, the increase in the $\mathrm{Cr}(\mathrm{VI})$ fraction on the surface is not attributed to an increase in the quantity of $\mathrm{Cr}(\mathrm{VI})$ adsorption. The changes in the ratio of $\mathrm{Cr}(\mathrm{VI})$ / $\mathrm{Cr}$ (III) is likely due phase transformation at the surface. As discussed earlier, nitrate could oxidize Fe(II) as long as a substantial quantity of nitrate is present. However, low nitrate does not effectively oxidize Fe(II), leaving some reduction capacity of magnetite. This might be the reason why more $\mathrm{Cr}$ (III) remained on the magnetite surface.

\section{Effects of $\mathrm{pH}$ on $\mathrm{Cr}$ surface speciation}

When \% $\mathrm{Cr}(\mathrm{VI})$ on the surface is compared at low and high $\mathrm{pH}$ values under the same ionic strength, there is a much larger difference in the two electrolyte systems at low $\mathrm{pH}$ values.

In the low sulfate media, $\% \mathrm{Cr}(\mathrm{VI})$ increased from $\sim 0.5$ to $\sim 60 \%$ with decreasing $\mathrm{pH}$ (Fig. $4 \mathrm{~b}$ ). At acidic $\mathrm{pH}, \mathrm{pH}$ dependent chromate adsorption was controlling the surface speciation at low sulfate concentration. It should be noted that, under acidic $\mathrm{pH}$ conditions, once reduction of the $\mathrm{Cr}(\mathrm{VI}) \mathrm{O}_{4}{ }^{2-}$ has occurred, $\mathrm{Cr}$ (III) cations might then be desorbed from the positively charged magnetite surface since it does not readily undergo a hydrolysis reaction to form $\mathrm{Cr}(\mathrm{III})(\mathrm{OH})_{3}$. This could account for the lower retention of $\mathrm{Cr}(\mathrm{III})$ on the surface at low $\mathrm{pH}$ values.

In the high sulfate media, \% $\mathrm{Cr}(\mathrm{VI})$ increased from $\sim 1$ to $\sim 22 \%$ with increasing $\mathrm{pH}$ (Fig. 4b). At alkaline $\mathrm{pH}$, auto oxidation of $\mathrm{Fe}(\mathrm{II})$ in magnetite is known to occur [12]. Newly formed Fe(III) oxyhydroxide facilitates the adsorption of $\mathrm{Cr}(\mathrm{VI})$. For $\mathrm{Cr}(\mathrm{VI})$ anions to be adsorbed at basic $\mathrm{pH}$, the $\mathrm{Cr}(\mathrm{VI})$ anion must undergo a ligand exchange reaction (i.e., inner-sphere) because of negatively charged mineral surfaces. For this reason, the effect of ionic strength of specific ligands (e.g., sulfate) on $\mathrm{Cr}$ (VI) adsorption occurs to a much lesser extent compared to those at low $\mathrm{pH}$. This supports the macroscopic observation in Fig. 1a. Because of diminished ligand effects at high $\mathrm{pH}$, the $\mathrm{Cr}(\mathrm{VI})$ sorption is more susceptible to changes in other physicochemical factors such as auto-oxidation and or the activity of $\mathrm{OH}^{-}$, which will induce the hydrolysis reaction of $\mathrm{Cr}$ (III). 

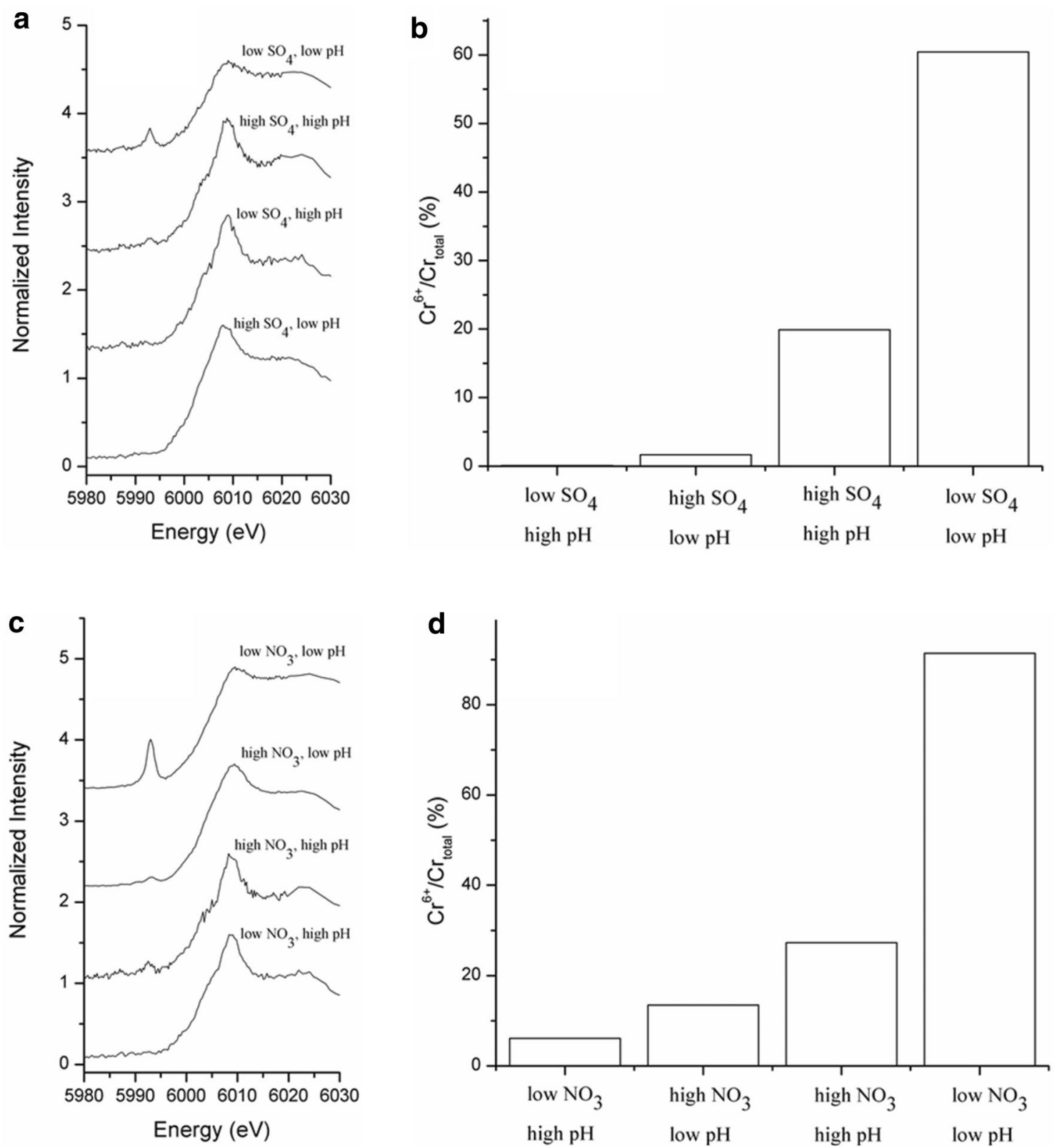

Fig. 4 Chromium surface speciation at the magnetite-water interface as a function of $\mathrm{pH}(4.02 \pm 0.1$ and $9.04 \pm 0.03)$ and electrolyte concentrations. High and low pH values correspond to $\mathrm{pH} 9$ and 4, respectively. a Pre-edge features of $\mathrm{Cr}$ XANES spectra from $\mathrm{Cr}(\mathrm{VI})$ reacted magnetite under $0.0016 \mathrm{M}_{(\mathrm{low} \mathrm{SO}}$ ) and $\left.0.016 \mathrm{M}^{(\mathrm{low} \mathrm{SO}}\right)_{4} \mathrm{Na}_{2} \mathrm{SO}_{4}$. b \% $\mathrm{Cr}(\mathrm{VI})$ fraction in the sorption samples shown in Fig. 4a. c Pre-edge features of Cr K-edge XANES spectra from $\mathrm{Cr}(\mathrm{VI})$ reacted magnetite under $0.01 \mathrm{M}$ (low $\mathrm{NO}_{3}$ ) and $0.1 \mathrm{M}$ (high $\mathrm{NO}_{3}$ ) $\mathrm{NaNO}_{3}$. d Data assessed by XANES pre-edge analysis shown in Fig. 4c. The fraction of \% $\mathrm{Cr}(\mathrm{VI})$ was estimated using the $\mathrm{Cr}(\mathrm{VI})$ standard curve in Fig. 3

In the nitrate medium, a similar $\mathrm{pH}$ effect is observed. However, the changes are even larger. In the low nitrate system, an incomplete reduction of $\mathrm{Cr}(\mathrm{VI})$ was observed. The amount of $\mathrm{Cr}(\mathrm{VI})$ retained was as high as $\sim 80 \%$ in the low nitrate media at low $\mathrm{pH}$. The observation of incomplete reduction of $\mathrm{Cr}(\mathrm{VI})$ in low $\left[\mathrm{NO}_{3}\right]$ agrees with previous reports $[4,37]$. Since low nitrate does not compete for the chromate adsorption, chromate anions are readily adsorbed on the surface. In the high nitrate media, however, \% $\mathrm{Cr}(\mathrm{VI})$ increased from $\sim 15$ to $\sim 28 \%$ with increasing pH (Fig. 4d). Similar to the high sulfate system, auto oxidation of $\mathrm{Fe}(\mathrm{II})$ in magnetite is expected at high $\mathrm{pH}$. Newly formed Fe(III) oxyhydroxide facilitated the adsorption of $\mathrm{Cr}(\mathrm{VI})$. 


\section{Kinetic effects on $\mathrm{Cr}$ surface speciation}

In the XANES analysis of equilibrium samples, it is clear that more $\mathrm{Cr}(\mathrm{III})$ is distributed in magnetite at alkaline $\mathrm{pH}$ in both nitrate and sulfate media (Fig. $4 \mathrm{~b}, \mathrm{~d}$ ). In other words, basic $\mathrm{pH}$ induced the hydrolysis of $\mathrm{Cr}$ (III) immediately after the $\mathrm{Cr}(\mathrm{VI})$ reduction. Several spectroscopic (e.g., X-ray photoelectron spectroscopy and X-ray absorption spectroscopy) studies reported the formation of $\mathrm{Cr}(\mathrm{OH})_{3}, \mathrm{Cr}(\mathrm{III}) \mathrm{OOH}_{(\mathrm{s})}$ and or $\mathrm{Cr}(\mathrm{III})$ bearing iron oxyhydroxide phases in the $\mathrm{Cr}(\mathrm{VI})$ reacted magnetite surfaces at pH 5-8 [15, 38, 39]. While these studies showed the $\mathrm{Cr}$ surface speciation in equilibrium based sorption experiments, they do not provide temporal scale information about the $\mathrm{Cr}(\mathrm{VI})$ reduction steps at the mineralwater interface. To assess the electron transfer reactions, time-resolved XANES measurements were conducted on kinetic samples at less than $12 \mathrm{~h}$. We chose samples at $\mathrm{pH} 4$ at low ionic strength in nitrate and sulfate media because these conditions yielded high $\mathrm{Cr}$ loading levels that allow us to evaluate the changes in $\mathrm{Cr}$ valence state during the short XANES experiments. Figure 5a and $\mathrm{c}$ show the pre-edge features of Cr XANES spectra in kinetic samples. Changes in \% $\mathrm{Cr}(\mathrm{VI})$ on the mineral surfaces are summarized in Fig. 5b, d. During the first $12 \mathrm{~h}$ of sorption experiments, approximately 78-86\% of total $\mathrm{Cr}$ on the surfaces was still $\mathrm{Cr}(\mathrm{VI})$ in both samples. Although there are some fluctuations in the data, it is clear that only $\sim 20 \%$ of total $\mathrm{Cr}$ on the surface was $\mathrm{Cr}(\mathrm{III})$.

The \% $\mathrm{Cr}(\mathrm{VI})$ fraction on the surface increases from 15 to $30 \mathrm{~min}$, suggesting that $\mathrm{Cr}(\mathrm{VI})$ adsorption was still occurring at the surfaces. Shortly after $30 \mathrm{~min}$, the amount of surface sorbed $\mathrm{Cr}(\mathrm{VI})$ decreases up to $\sim 3 \mathrm{~h}$. This suggests the reduction of $\mathrm{Cr}(\mathrm{VI})$ occurred. Interestingly, between 3 and $12 \mathrm{~h}$, there was an increase in the $\mathrm{Cr}(\mathrm{VI})$ fraction to $\sim 80 \%$. Our interpretation is as follows. $\mathrm{Cr}(\mathrm{VI})$ reduction occurred up to $\sim 3 \mathrm{~h}$, and then electron transfer reaction was suppressed due to the formation of $\mathrm{Cr}$ (III) hydroxide surface precipitates. While the formation of a $\mathrm{Cr}(\mathrm{III})(\mathrm{OH})_{3}(\mathrm{~s})$ passivation layer can be one of explanations for the inhibitory mechanism [8-11], the transformation of adsorbent can also be pointed out at this low $\mathrm{pH}$. During the $\mathrm{Cr}(\mathrm{VI})$ reduction, the depletion of $\mathrm{Fe}(\mathrm{II})$ from magnetite structure is simultaneously occurring. Both XRD and TEM analyses showed the transformation of magnetite to goethite and or maghemite $\left(\gamma-\mathrm{Fe}_{2} \mathrm{O}_{3}\right)$ and then hematite $\left(\alpha-\mathrm{Fe}_{2} \mathrm{O}_{3}\right)$ under oxidized conditions [40]. A structural polymorph of hematite is the most common weathering product of magnetite in oxic environments. The formation of a passivation layer can also be facilitated by sulfate promoted Fe(II) dissolution. Sulfate ions could also complex with $\mathrm{Fe}(\mathrm{II})$, and increase the dissolution of $\mathrm{Fe}(\mathrm{II})$ from the magnetite structure $[7,41]$. Depending on the reaction $\mathrm{pH}$, the dissolved $\mathrm{Fe}(\mathrm{II})$ can precipitate as $\mathrm{Fe}(\mathrm{OH})_{2}$, and eventually oxidize to form a ferrihydrite/goethite passivation layer.

\section{EXAFS Analysis of steady state samples}

Additional EXAFS analyses were conducted on sorption samples after $42 \mathrm{~h}$ (Fig. 6). The results are summarized in Fig. 6 and Table 1. Based on the fraction fit of oxygen shells, $\sim 54( \pm 7) \%$ of total $\mathrm{Cr}$ on the surface was $\mathrm{Cr}(\mathrm{VI})$ in the low sulfate system at $\mathrm{pH} 4$ whereas the amount of $\mathrm{Cr}(\mathrm{VI})$ was slightly lower in the low nitrate system, $49( \pm 7) \%$. The difference can be seen in the position of first shell in radial structural functions (Fig. 6a). The position of the vertical dotted line is aligned at the peak of first shell in the nitrate sample. The peak position of first shell in the sulfate system is slightly lower that in the nitrate system, supporting the result of $\mathrm{Cr}$ valence analysis. Second and third shell features at $\sim 3.0$ and $3.5 \AA$ were successfully fit with either $\mathrm{Cr}$ or Fe because of similar photo electronic scattering properties of these elements. The distance can be interpreted as a mixture of adsorbed $\mathrm{Cr}(\mathrm{VI}) \mathrm{O}_{4}, \mathrm{Cr}(\mathrm{III}) \mathrm{O}_{6}$ and or co-precipitated $\mathrm{Cr}(\mathrm{III}) \mathrm{O}_{6}$.

Based on the first shell analysis, it is clear that both $\mathrm{Cr}(\mathrm{VI}) \mathrm{O}_{4}$ and $\mathrm{Cr}(\mathrm{III}) \mathrm{O}_{6}$ surface species are present. Coordination number of $\mathrm{Cr}-\mathrm{Cr} / \mathrm{Fe}$ distance at $2.91 \AA$ is about one. This corresponds to the edge sharing mononuclear $\mathrm{Cr}(\mathrm{VI}) \mathrm{O}_{4}$ on $\mathrm{FeO}_{6}$ in goethite [38]. Edge sharing mononuclear $\mathrm{Cr}(\mathrm{III})$ on $\mathrm{FeO}_{6}$ in goethite [42] can be also considered along with $\mathrm{Cr}(\mathrm{III})$ co-precipitates [43]. A distance $\left(2.98 \AA\right.$ ), which is consistent with edge of two $\mathrm{MeO}_{6}$ polyhedral with $\mathrm{Me}$ as $\mathrm{Fe}$ and or $\mathrm{Cr}$, was reported in the XAS analysis of $\mathrm{Cr}(\mathrm{III})$ surface precipitates $(\gamma-\mathrm{CrOOH})$ in ferrihydrite at $\mathrm{pH} 4$ [43]. Feff/XRD generated $\mathrm{Cr}-\mathrm{Cr}$ interatomic distance in bracewellite, $\mathrm{CrO}(\mathrm{OH})$, at $2.97 \AA$ [44].

There is an additional $\mathrm{Cr}-\mathrm{Cr} / \mathrm{Fe}$ shell at $\sim 3.5 \AA$ in both samples. The similar distance was previously reported as multinuclear $\mathrm{Cr}$ surface species on the hematite (0001) surface via grazing incident-XAFS analysis [45]. Double corner sharing of $\mathrm{CrO}_{6}$ to $\mathrm{Cr} / \mathrm{FeO}_{6}$ yields in a similar distance [42]. Feff/XRD simulation of bracewellite structure shows the $\mathrm{Cr}-\mathrm{Cr}$ interatomic distance of $\sim 3.4 \AA$. The $\mathrm{Cr}-$ Fe distance of 3.4 $\AA$ was reported in $\mathrm{Cr}$ (III) substituted $\alpha-\mathrm{FeOOH}[48]$.

\section{Conclusions}

Magnetite readily removed dissolved $\mathrm{Cr}(\mathrm{VI})$ from solution in the presence of nitrate and sulfate. Like other oxyanions, sorption of $\mathrm{Cr}(\mathrm{VI})$ increases with decreasing $\mathrm{pH}$. While the effects of ionic strength were more pronounced in sulfate media than nitrate media, total $\mathrm{Cr}$ retention was greater in sulfate solutions than in nitrate solutions. The oxidation of Fe(II) (as surface bound or 

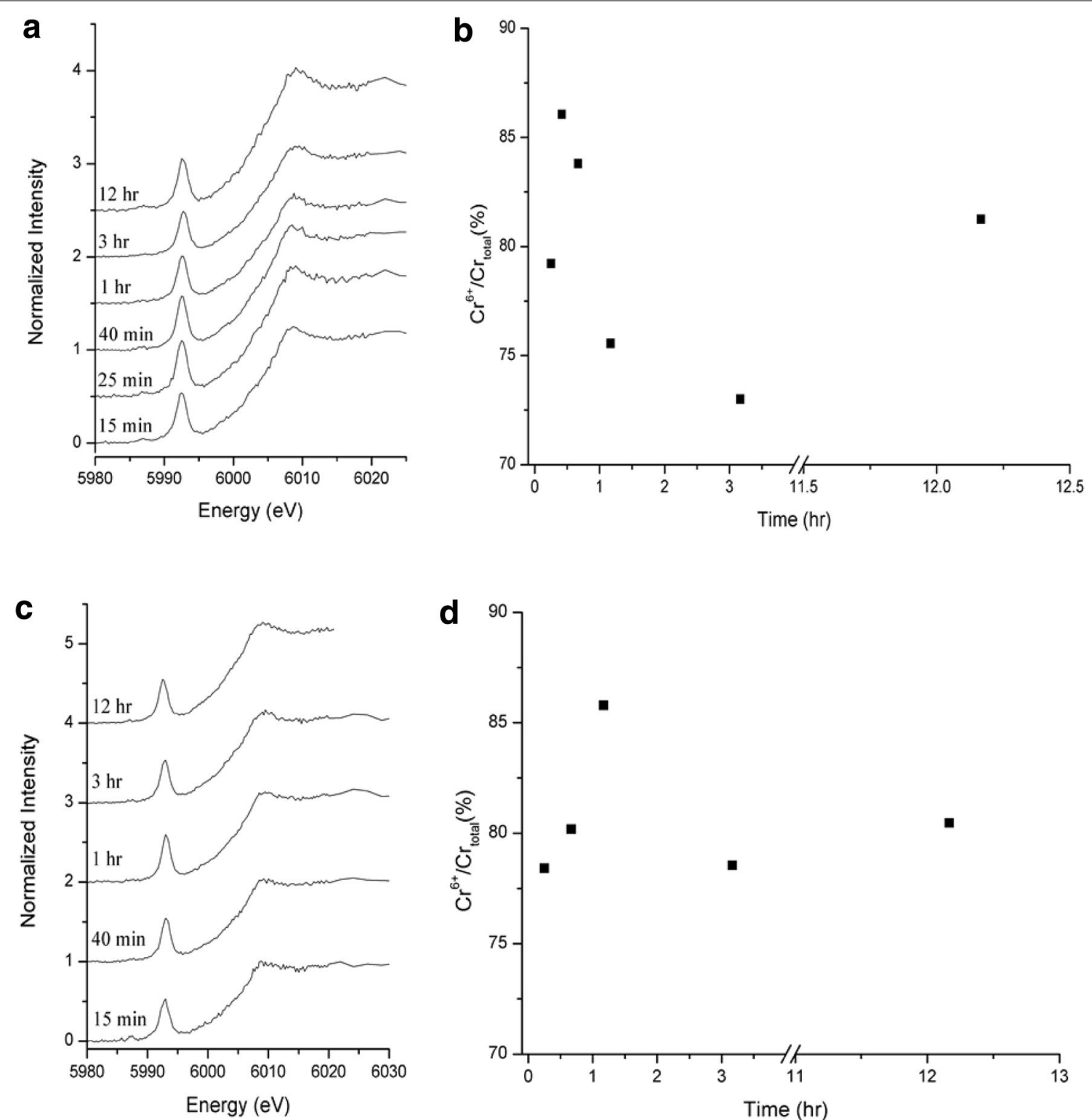

Fig. $5 \mathrm{Cr}$ surface speciation via pre-edge features of $\mathrm{Cr}$ K-edge XANES analysis of $\mathrm{Cr}(\mathrm{VI})$ sorption kinetic samples. a $0.016 \mathrm{M} \mathrm{Na}_{2} \mathrm{SO}_{4}$ at pH $4.01 \pm 0.10$. b Changes in $\mathrm{Cr}$ surface speciation from data assessed by XANES pre-edge analysis shown in Fig. 5a. c $0.01 \mathrm{M} \mathrm{NaNO}_{3}$ at pH $4.01 \pm 0.10$. d Changes in $\mathrm{Cr}$ speciation from data assessed by XANES pre-edge analysis shown in Fig. $5 \mathrm{C}$

crystal defects) in magnetite by nitrate suppressed $\mathrm{Cr}(\mathrm{VI})$ reduction, resulting in less $\mathrm{Cr}$ removal in nitrate media. In sulfate media, competitive adsorption of sulfate was more of an important factor at acidic $\mathrm{pH}$. XANES analysis revealed that the $\mathrm{Cr}(\mathrm{VI})$ surface reduction occurred at high $\mathrm{pH}$ in low ionic strength $(0.01 \mathrm{M})$ of both electrolytes. However, such electron transfer reactions were suppressed at low $\mathrm{pH}$, resulting in more adsorbed $\mathrm{Cr}(\mathrm{VI})$ on the surfaces. Because of the structural alternation of adsorbent (i.e., formation of passivation layers such as $\mathrm{Cr}(\mathrm{III})$ precipitates and $\mathrm{Fe}(\mathrm{III})$ oxyhydroxides), the kinetics of $\mathrm{Cr}(\mathrm{VI})$ reduction was slow after $3 \mathrm{~h}$ as evident in the XANES and EXAFS analysis. Adsorbed $\mathrm{Cr}(\mathrm{VI})$ surface species dominated during the initial several hrs, and nearly $50 \%$ of total $\mathrm{Cr}$ on the surface was adsorbed $\mathrm{Cr}(\mathrm{VI})$ anions in both sulfate and nitrate media. This suggests that adsorption processes of $\mathrm{Cr}(\mathrm{VI})$ anions on magnetite surfaces is as important as the reductive 

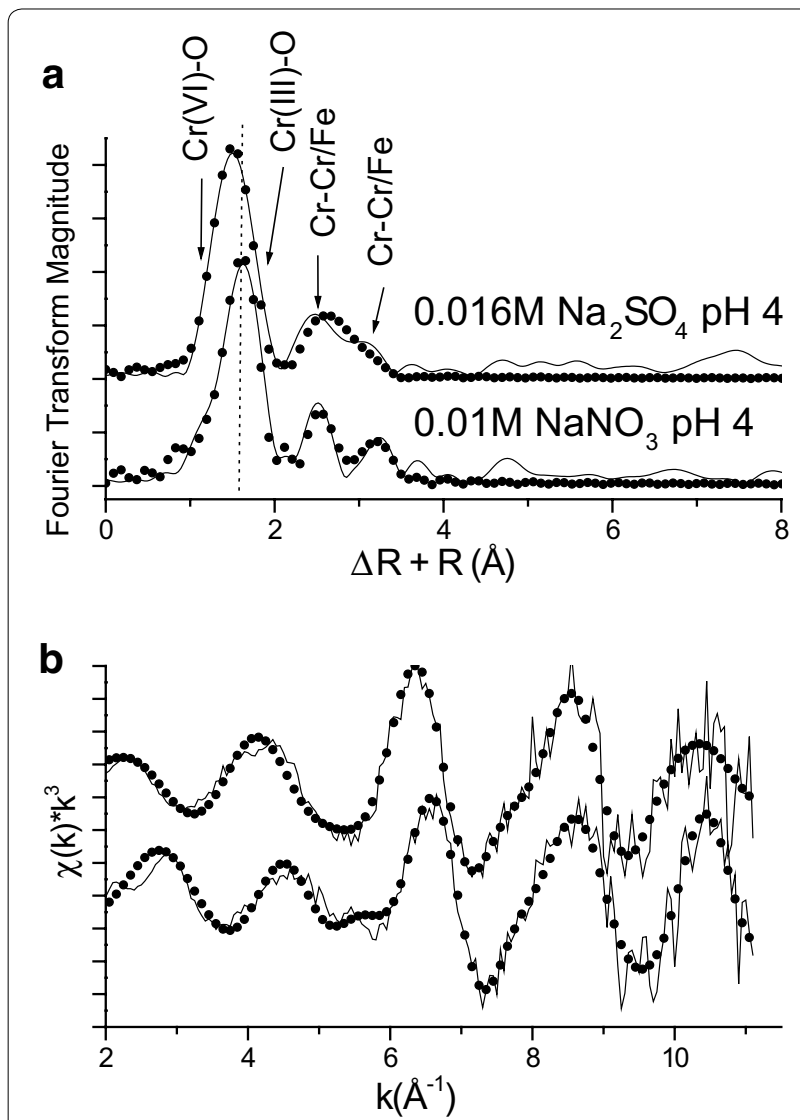

Fig. 6 a Non-linear least-squares fit of normalized $k^{3}$-weighted EXAFS spectra of $\mathrm{Cr}(\mathrm{VI})$ reacted magnetite after $48 \mathrm{~h}$. A vertical dotted line is aligned at the peak of first shell of a bottom spectrum. $\mathbf{b}$ Corresponding Fourier transformed radial structural function (uncorrected for phase shift of backscattering atom) of EXAFS spectra. Solid lines and filled black circles represent normalized raw data and fit, respectively

precipitation of $\mathrm{Cr}(\mathrm{III})$ in explaining the removal of $\mathrm{Cr}(\mathrm{VI})$ with magnetite. In assessing the stability of sorbed $\mathrm{Cr}$ in magnetite, it might be important to consider the desorption process of $\mathrm{Cr}(\mathrm{VI})$ anions with respect to common ions in natural waters.

\section{Experimental}

Materials

Synthetic magnetite $\left(\mathrm{Fe}_{3} \mathrm{O}_{4}\right)$ nanopowder was obtained from Nanostructured and Amorphous Materials, Inc. (Houston, TX) Particle size was 50-100 nm with >99\% purity. The following ACS grade chemicals were prepared in degassed ultrapure water (18.2 $\mathrm{M} \Omega$ ): sodium nitrate, sodium sulfate, nitric acid, sulfuric acid, and sodium hydroxide. Solutions of ACS grade sodium chromate tetrahydrate, sodium acetate, and 3-propanesulfonic acid (MOPSO) were prepared in $0.01 \mathrm{M}$ and $0.1 \mathrm{M} \mathrm{NaNO}_{3}$ and $0.0016 \mathrm{M}$ and $0.016 \mathrm{M} \mathrm{Na}_{2} \mathrm{SO}_{4}$. These concentrations represent 0.01 and 0.1 ionic strengths for the background solutions, respectively. Standards were prepared using the NIST traceable ICP-MS standard ammonium dichromate $(1000 \mathrm{mg} / \mathrm{L} \mathrm{Cr}$ in $3 \%$ nitric acid, $99 \%$, Ricca Chemical Company). The ACS grade chemicals potassium chromate $[\mathrm{Cr}(\mathrm{VI})]$ and chromium oxide [ $\mathrm{Cr}(\mathrm{III})]$ were used for the $\mathrm{X}$-ray energy calibration.

\section{PZSE determination}

Potentiometric acid-base titrations were conducted using $0.2 \mathrm{~g} / \mathrm{L}$ magnetite nanopowder in $0.01,0.05$ and $0.1 \mathrm{M} \mathrm{NaNO}_{3}$ backgrounds. Solutions were prepared in individual $50 \mathrm{~mL}$ Nalgene polypropylene sterile highperformance (PS) centrifuge tubes. The nanopowder was hydrated for $24 \mathrm{~h}$ on an end-over-end shaker at $20 \mathrm{rpm}$; afterwards a predetermined amount of 0.01-0.1 M $\mathrm{NaOH}$ and $\mathrm{HNO}_{3}$ were added to each tube resulting in an approximate $\mathrm{pH}$ range of 3-10. The samples were then shaken on an end-over shaker for $24 \mathrm{~h}$. The final $\mathrm{pH}$ values were plotted against total acid concentration and the point of intersection in the batch titration curves was used to find the point of zero salt effect (PZSE) [46].

\section{Batch sorption experiments}

Magnetite suspensions were prepared in $5 \mathrm{~g} / \mathrm{L}$ solid to solution ratio in $50 \mathrm{~mL}$ PS high-performance centrifuge tubes. Samples were hydrated in 0.001, 0.1 $\mathrm{M} \mathrm{NaNO}_{3}$,

Table 1 Least square analysis of Cr K-edge XAS spectra

\begin{tabular}{|c|c|c|c|c|c|c|c|c|}
\hline Sample & & $\mathrm{Cr}(\mathrm{VI})-\mathrm{O}$ & $\mathrm{Cr}(\mathrm{III})-\mathrm{O}$ & $\mathrm{Cr}-\mathrm{Cr} / \mathrm{Fe}$ & $\mathrm{Cr}-\mathrm{Cr} / \mathrm{Fe}$ & $\% \operatorname{Cr}(\mathrm{VI})$ & $\% \operatorname{Cr}(\mathrm{III})$ & R-factor \\
\hline $\mathrm{pH} 4( \pm 0.02)$ & $\mathrm{CN}$ & $4^{a}$ & $6^{a}$ & $1.3(3)$ & $0.4(2)$ & & & \\
\hline $0.016 \mathrm{M}$ & $\mathrm{R}$ & $1.60(1)$ & $1.99(1)$ & $3.03(2)$ & $3.44(3)$ & $54( \pm 7)$ & $46( \pm 7)$ & 0.017 \\
\hline $\mathrm{Na}_{2} \mathrm{SO}_{4}$ & $\sigma^{2}$ & $0.005(2)$ & $0.003(1)$ & $0.007^{a}$ & $0.002(1)$ & & & \\
\hline $\mathrm{pH} 4( \pm 0.02)$ & $\mathrm{CN}$ & $4^{a}$ & $6^{a}$ & $1.2(1)$ & $0.6(3)$ & & & \\
\hline $0.01 \mathrm{M}$ & $\mathrm{R}$ & $1.65(1)$ & $1.98(1)$ & $3.00(3)$ & $3.48(2)$ & $49( \pm 7)$ & $51( \pm 7)$ & 0.030 \\
\hline $\mathrm{NaNO}_{3}$ & $\sigma^{2}$ & $0.008(4)$ & $0.016(1)$ & $0.007^{a}$ & $0.002(1)$ & & & \\
\hline
\end{tabular}

Estimated errors for $\mathrm{CN}: \pm 20 \%$ and $\mathrm{R}: \pm 0.01 \AA$ [12]

CN Coordination number, $R$ inter atomic distances $(\AA)$, $\sigma^{2}$ Debye-Waller factor $\left(\AA^{2}\right)$

a Fixed parameters for the first $\mathrm{Cr}-\mathrm{Cr} / \mathrm{Fe}$ shell is according to the study [12] 
0.0016 or $0.016 \mathrm{M} \mathrm{Na}_{2} \mathrm{SO}_{4}$ degassed background solutions for $10 \mathrm{~h}$ on an end-over-end shaker at $30 \mathrm{rpm}$. It is important to note that no magnetic stir bar was used due to the magnetic property of magnetite. $\mathrm{pH}$ values were adjusted before and after hydration using 0.01-1 M $\mathrm{NaOH}$ and either $\mathrm{H}_{2} \mathrm{SO}_{4}$ or $\mathrm{HNO}_{3}$ depending on the background electrolyte. Samples were prepared over an approximate $\mathrm{pH}$ range of 3-12; no buffer was used. The solutions were spiked with $0.5 \mathrm{mM} \mathrm{Na} \mathrm{CrO}_{4} \cdot 4 \mathrm{H}_{2} \mathrm{O}$ and returned to the shaker for $24 \mathrm{~h}$. After the experiment the $\mathrm{pH}$ of each sample was recorded and aliquots were collected, filtered through a $0.2 \mu \mathrm{m}$ polyvinylidene fluoride (PVDF) filter. Filtrates were diluted with $1 \%$ Suprapur $^{\circledR}$ nitric acid, and then analyzed using an inductively coupled plasma mass spectrometer (ICP-MS) Thermo Scientific X Series 2 that was calibrated using a Cr(VI) NIST traceable ICP-MS standard. The $\mathrm{Cr}(\mathrm{VI})$ was assured using a spectrophotometric method [47].

\section{XAS analysis}

All XAS samples were prepared at room temperature. Kinetic samples were freshly prepared at the Stanford Synchrotron Radiation Laboratory (SSRL), Menlo Park, CA. For equilibrium samples, sorption samples were prepared at $10 \mathrm{~g} / \mathrm{L}$ for collection and analysis purposes. The hydration, spiking, and aliquot collection procedure were identical to the sorption experiments. Kinetic samples for $\mathrm{X}$-ray absorption near edge structure (XANES) analysis were prepared in $50 \mathrm{~mL}$ high-performance centrifuge tubes with $5 \mathrm{~g} / \mathrm{L}$ solid to solution ratio with either $0.01 \mathrm{M}$ $\mathrm{NaNO}_{3}$ or $0.016 \mathrm{M} \mathrm{Na}_{2} \mathrm{SO}_{4}$ and acidic $\mathrm{pH}(4.01 \pm 0.10)$. Acidic $\mathrm{pH}$ was chosen because of this reaction condition provides sufficient $\mathrm{Cr}$ loading level for rapid (i.e., single scan) XANES measurements. Sodium acetate $(50 \mathrm{mM})$ was used as a buffer solution. Tubes were placed on an end-over-end shaker at $30 \mathrm{rpm}$ and one tube was sacrificed for each time interval. Mineral suspensions were spiked with $1 \mathrm{mM} \mathrm{Na} \mathrm{CrO}_{4} \cdot 4 \mathrm{H}_{2} \mathrm{O}$ and sampled at 15, 25, $40 \mathrm{~min}$, and 1, 3, $12 \mathrm{~h}$. Each sample was filtered using vacuum filtration on PVDF filter papers, trapped between Kapton tape, and immediately analyzed at the beamtime. We chose the room temperature analysis with one scan over the cryo measurements since the sample loading time in a cryo cell and holder requires more than $5 \mathrm{~min}$. For the extended X-ray absorption fine structure spectroscopy (EXAFS) measurement, equilibrium samples after $48 \mathrm{~h}$ were used.

All samples were analyzed at beam line $4-3$ at SSRL. The electron storage ring was operated at $3 \mathrm{Ge} \mathrm{V}$ energy with a current range of $80-100 \mathrm{~mA}$. The energy calibration was performed at 5989 e $\mathrm{V}$ using the first derivative of a $\mathrm{Cr}$ foil XANES spectrum. Fluorescence-yield $\mathrm{Cr}$ K-edge spectra were collected using a 4 element vortex detector. The monochromator was a $\mathrm{Si}(111)$ double-crystal with a non-fixed exit slit. Sample holders were oriented at $45^{\circ}$ to the unfocused incident beam. All samples were run at room temperature.

To assess the change in $\mathrm{Cr}$ valence state at the mineral-water interface during the sorption reaction, a $\mathrm{Cr}$ pre-edge peak standard curve was constructed using the Cr K-edge pre-edge peak of $\mathrm{Cr}(\mathrm{VI}) / \mathrm{Cr}(\mathrm{III})$ mixtures. All reference spectra were collected in transmission mode. The reference salts, $\mathrm{K}_{2} \mathrm{Cr}(\mathrm{VI}) \mathrm{O}_{4}$ and $\mathrm{Cr}_{2}(\mathrm{III}) \mathrm{O}_{3}$, were mixed to give a range $(0-100 \%)$ of $\mathrm{Cr}(\mathrm{VI})$ concentration, ground with a diamonite mortar and pestle, and the fine powder was trapped in Kapton tape.

The data reduction of bulk XANES spectra was performed using the SixPACK/IFEFFIT interface [48]. Because of fast sorption reactions, only one spectrum was collected per kinetic sample. The following data normalization was carried out at approximately 5800$6150 \mathrm{eV}$. A Gaussian function was used for normalization of the pre-edge region and a quadratic function was used for the post-edge region. Extended X-ray absorption fine structure spectroscopy analysis was conducted in two equilibrium sorption samples after $42 \mathrm{~h}$ according to the method described in Arai and Livi [49]. Only two spectra were averaged and splined up to $11.1 \AA^{-1}$. Because of only two scans, any noise in Fourier transformed radial structural function (RSF) feature $>3.6 \AA$ was unable to be fit. The structural refinement data of chromite and $\mathrm{K}_{2} \mathrm{CrO}_{4}$ were used to generate single scattering paths for $\mathrm{Cr}(\mathrm{III})-\mathrm{O}, \mathrm{Cr}(\mathrm{VI})-\mathrm{O}, \mathrm{Cr}(\mathrm{III})-\mathrm{O}$ and $\mathrm{Cr}-\mathrm{Fe}$ [50, 51]. In order to assess the fraction of $\mathrm{Cr}(\mathrm{III})$ and $\mathrm{Cr}(\mathrm{VI})$, a sum of each fraction was set to unity, and each fraction was multiply to $\mathrm{CN}$ of each $\mathrm{Cr}$ path. Based on tetrahedral structure of $\mathrm{Cr}(\mathrm{VI})$ and octahedral structure of $\mathrm{Cr}(\mathrm{III})$, $\mathrm{CN}$ was fixed at 4 and 6 , respectively. The rest of fitting parameters were floated unless otherwise mentioned in the text.

\section{Authors' contributions \\ AHM conducted batch experiments and characterization of magnetite. AHM and YA both collected the XAS data and process the data for the XANES analysis. YA was responsible for EXAFS analysis of $\mathrm{Cr}$ reacted magnetite. The MS was contributed by both authors. All authors read and approved the final manuscript.}

\section{Author details}

School of Agricultural, Forest and Environmental Sciences, Clemson University, Clemson, SC 29634, USA. ${ }^{2}$ Department of Natural Resources and Environmental Sciences, University of Illinois at Urbana-Champaign, Urbana, IL 61801, USA.

\section{Acknowledgements}

This research was supported by the NIFA hatch fund (1-600116-875000875939) and the South Carolina Universities Research and Education Foundation, Contract No. DE-AC09-08SR22470. Portions of this work were performed at BL4-3 at SSRL. These facilities are supported by the U.S. Department of Energy, Office of Science, Office of Basic Energy Sciences under Contract No. DE-AC02-76SF00515. 


\section{Competing interests}

The authors declare they have no competing interests.

Received: 4 January 2016 Accepted: 15 April 2016

Published online: 29 April 2016

\section{References}

1. U.S. Environmental Protection Agency (EPA) Toxicological review of hexavalent chromium. National Center for Environmental Assessment, Office of Research and Development, Washington. (1998)

2. National Toxicology Program (NTP) NTP technical report on the toxicology and carcinogenesis studies of sodium dichromate dihydrate (CAS No. 7789-12-0) in F344/N rats and B6C3F1 mice (Drinking water studies). NTP TR 546, NIH Publication No. 07-5887: National Toxicology Program, National Institutes of Health, U.S. Department of Health and Human Services (2008). http://ntp.niehs.nih.gov/files/546_web_FINAL.pdf

3. Office of Environmental Health Hazard Assessment (OEHHA) Draft Public Health Goal for Hexavalent Chromium in Drinking Water: Pesticide and Environmental Toxicology Branch, Office of Environmental Health Hazard Assessment, California Environmental Protection Agency (2009).ss www. oehha.ca.gov/water/phg/pdf/Cr6PHGdraft082009.pdf

4. HeY (2003) Chromate reduction and immobilization under high $\mathrm{pH}$ and high ionic strength. Ph.D. Dissertation, Ohio State University

5. He YT, Chen C, Traina SJ (2004) Inhibited $\mathrm{Cr}(\mathrm{VI})$ reduction by aqueous Fe(II) under hyperalkaline conditions. Environ Sci Technol 38:5535-5539

6. Mohan D, Pittman CU Jr (2006) Activated carbons and low cost adsorbents for remediation of tri-and hexavalent chromium from water. J Haz Mater 137:762-811

7. White AF, Peterson ML (1996) Reduction of aqueous transition metal species on the surfaces of Fe(II)-containing oxides. Geochim Cosmochim Acta 60:3799-3814

8. Kendelewicz T, Liu P (2000) Spectroscopic study of the reaction of aqueous $\mathrm{Cr}(\mathrm{VI})$ with $\mathrm{Fe}_{3} \mathrm{O}_{4}$ (111) surfaces. Surf Sci 469:144-163

9. Grossl PR, Eick MJ, Sparks DL, Goldberg S, Ainsworth CC (1997) Arsenate and chromate retention mechanisms on goethite. 2.Kinetic evaluation using a pressure-jump relaxation technique. Environ Sci Technol 31(2):321-326

10. Rai D, Sass BM, Moore DA (1987) Chromium(III) hydrolysis constants and solubility of chromium(III) hydroxide. Inorg Chem 26:345-349

11. Sass BM, Rai D (1987) Solubility of amorphous chromium(III)-iron(III) hydroxide solid solutions. Inorg Chem 26(14):2228-2232

12. He YT, Traina SJ (2005) $\mathrm{Cr}(\mathrm{VI})$ reduction and immobilization by magnetite under alkaline $\mathrm{pH}$ conditions: the role of passivation. Environ Sci Technol 39:4499-4504

13. Bard AJ, Parsons R, Jordan J (1985) Standard potentials in aqueous solution. Marcel Dekker Inc, New York, p 6

14. Walther JV (2009) Essentials of Geochemistry. Jones \& Bartlett Learning; 2 edition. Sudbury, MA

15. Kendelewicz T, Liu P, Doyle C, Brown GE Jr, Nelson Chambers ES (1999) S. X-ray absorption and photoemission study of the adsorption of aqueous $\mathrm{Cr}(\mathrm{VI})$ on single crystal hematite and magnetite surfaces. Surf Sci 424:219-231

16. Peterson ML, Brown GE Jr, Parks GA (1996) Direct XAFS evidence for heterogeneous redox reaction at the aqueous chromium/magnetite interface. Colloid Surface A 107:77-88

17. Nollet LML, De Gelder LSP (2000) Handbook of water analysis. CRC Press, Marcel Dekker, Inc., New York, p 201

18. Lens PNL, Visser A, Janssen AJH, Pol LWH, Lettinga G (1998) Biotechnological treatment of sulfate-rich wastewaters. Crit Rev Environ Sci Technol 28:41-88

19. Kosmulski M (2009) Compilation of PZC and IEP of sparingly soluble metal oxides and hydroxides from literature. Adv Colloid Interf Sci 152:14-25

20. Regazzoni AE, Blesa MA, Maroto AJ (1983) Interfacial properties of zirconium dioxide and magnetite in water. Colloid Interf Sci 91:560-570

21. Salazar-Camacho C, Villalobos M, Rivas-Sanchez M, Arenas-Alatorre J, Alcaraz-Cienfuegos J, Gutierrez-Reuiz M (2013) Characterization and surface reactivity of natural and synthetic magnetites. Chem Geol 347:233-245

22. Catalette H, Dumonceau J, Ollar PJ (1998) Sorption of cesium, barium and europium on magnetite. Cont. Hydrol. 35:151-159

23. Plaza R, Arias J, Espın M, Jiménez M, Delgado A (2002) Aging effects in the electrokinetics of colloidal iron oxides. J Colloid Interf Sci 245:86-90

24. Tombácz E, Illés E, Majzik A, Hajdú A, Rideg N, Szekeres M (2007) Aging in the inorganic nanoworld: example of magnetite nanoparticles in aqueous medium. Croat Chem Acta 80:503-515

25. Kosmulski MJ (2011) The $\mathrm{pH}$-dependent surface charging and points of zero charge: $\bigvee$. Update. J Colloid Interf Sci 353:1-15

26. Milonjić $S$, Kopečni M, Ilić Z (1983) The point of zero charge and adsorption properties of natural magnetite. J Radioanal Nuc Chem 78:15-24

27. Parsons JG, Hernandez J, Gonzalez CM, Gardea-Torresdey JL (2014) Sorption of $\mathrm{Cr}(\mathrm{III})$ and $\mathrm{Cr}(\mathrm{VI})$ to high and low pressure synthetic nano-magnetite $\left(\mathrm{Fe}_{3} \mathrm{O}_{4}\right)$ particles. Chem Eng J 254:171-180

28. Tokunaga TK, Wan J, Firestone MK, Hazen TC, Schwartz E, Sutton SR, Newville M (2011) Chromium diffusion and reduction in soil aggregates. Environ Sci Technol 35:3169-3174

29. Gustafsson JP (2007) Visual MINTEQ. Visual Minteq. Version 3.0. Division of land and water resources, Royal Institute of Technology. Stockholm. http://www.lwr.kth.se/English/OurSoftware/vminteq/index.htm

30. Washburn EW, West CJ (1929) International critical tables of numerical data, physics, chemistry and technology; National Academies.7

31. Gallios GP, Vaclavikova M (2008) Removal of Chromium (VI) from Water Streams: a Thermodynamic Study. Environ Chem Lett 6:235-240

32. Hayes KF, Redden G, Ela W, Leckie JOJ (1991) Surface complexation models: an evaluation of model parameter estimation using FITEQL and oxide mineral titration data. J Colloid Interf Sci 142:448-469

33. Fendorf SE, Eick MJ, GrossI P, Sparks DL (1997) Arsenate and chromate retention mechanisms on goethite. 1. Surface structure. Environ Sci Technol 31:315-320

34. Peak D, Ford RG, Sparks DL (1999) An in Situ ATR-FTIR investigation of sulfate bonding mechanisms on goethite. J Colloid Interf Sci 218:289-299

35. Wijnja H, Schulthess CP (2000) Vibrational spectroscopy study of selenate and sulfate adsorption mechanisms on Fe and Al (hydr) oxide surfaces. J Colloid Interf Sci 229:286-297

36. Zhang PC, Sparks DL (1990) Kinetics and mechanisms of sulfate adsorption/desorption on goethite using pressure-jump relaxation. Soil Sci Soc Am J 54:1266-1273

37. Chambers S, Brown, Jr. GE, Amonette J, Dixon D, Joyce S, Rustad J (1997) Molecular-level processes governing the interaction of contaminants with iron and manganese oxides. Pacific Northwest National Laboratory. 67Chambers S, Brown, Jr. GE, Amonette J, Dixon D, Joyce S, Rustad J (1997) Molecular-level processes governing the interaction of contaminants with iron and manganese oxides. Pacific Northwest National Laboratory. 67

38. Jung Y, Choi J, Lee W (2007) Spectroscopic investigation of magnetite surface for the reduction of hexavalent chromium. Chemosphere 68:1968-1975

39. Peterson ML, Brown GE Jr, Parks GA, Stein CL (1997) Differential redox and sorption of $\mathrm{cr}$ (iii/vi) on natural silicate and oxide minerals: EXAFS and XANES results. Geochim Cosmochim Acta 61:3399-3412

40. Brown GE Jr, Henrich VE, Casey WH, Clark DL, Eggleston C, Felmy A, Goodman DW, Grätzel M, Maciel G, McCarthy MI (1999) Metal oxide surfaces and their interactions with aqueous solutions and microbial organisms. Chem Rev 99:77-174

41. Chowdhury SR, Yanful EK (2010) Arsenic and chromium removal by mixed magnetite-maghemite nanoparticles and the effect of phosphate on removal. J Environ Manag 91:2238-2247

42. Charlet L, Manceau A (1992) X-ray absorption spectroscopic study of the sorption of $\mathrm{Cr}(\mathrm{III})$ at the oxide/water interface. II Adsorption, coprecipitation, and surface precipitation on hydrous ferric oxide. J Colloid Interf Sci 148:443-458

43. Manceau A, Charlet $L$ (1992) X-ray absorption spectroscopic study of the sorption of $\mathrm{Cr}(\mathrm{III})$ at the oxide-water interface: I. Molecular mechanism of Cr(III) oxidation on Mn oxides. J Colloid Interf Sci 148:425-442

44. Milton C, Appleman DE, Appleman MH, Chao ECT, Cuttitta F, Dinnin Jl, Dwornik EJ, Ingramand BL, Rose BL, Jr Ingramand HJ (1976) Merumite, a complex assemblage of chromium minerals from Guyana. US Geol Suns Prof Pap 887:1-29 
45. Grolimund D, Trainor TP, Fitts JP, Kendelewicz T, Liu P, Chambers SA, Brown GE Jr (1999) Identification of $\mathrm{Cr}$ species at the aqueous solution-hematite interface after $\mathrm{Cr}(\mathrm{VI})$ - $\mathrm{Cr}(\mathrm{III})$ reduction using GI-XAFS and $\mathrm{Cr}$ L-edge NEXAFS. J Synchrotr 6:612-614

46. Lützenkirchen J, Preočanin T, Kovačević D, Tomišić V, Lövgren L, Kallay N (2012) Potentiometric titrations as a tool for surface charge determination. Croat Chem Acta 85:391-417

47. Bartlett R, James B (1979) Behavior of chromium in soils: III Oxidation. J Environ Qual 8:31-35
48. Webb S (2005) SIXpack: A graphical user interface for XAS analysis using IFEFFIT. Physica Scripta 1011

49. Arai Y, Livi K (2012) Under assessed phosphorus fixation mechanisms in soil sand fractions. Geoderma 192:422-429

50. Hill RJ, Craig JR, Gibbs GV (1979) Systematics of the spinel structure type. Phys Chem Miner 4:317-339

51. McGinnety JA (1972) Redetermination of the structures of potassium sulphate and potassium chromate: the effect of electrostatic crystal forces upon observed bond lengths. Acta Cryst B28:2845-2852

\section{Submit your manuscript to a SpringerOpen ${ }^{\circ}$ journal and benefit from:}

- Convenient online submission

- Rigorous peer review

- Immediate publication on acceptance

- Open access: articles freely available online

- High visibility within the field

- Retaining the copyright to your article 